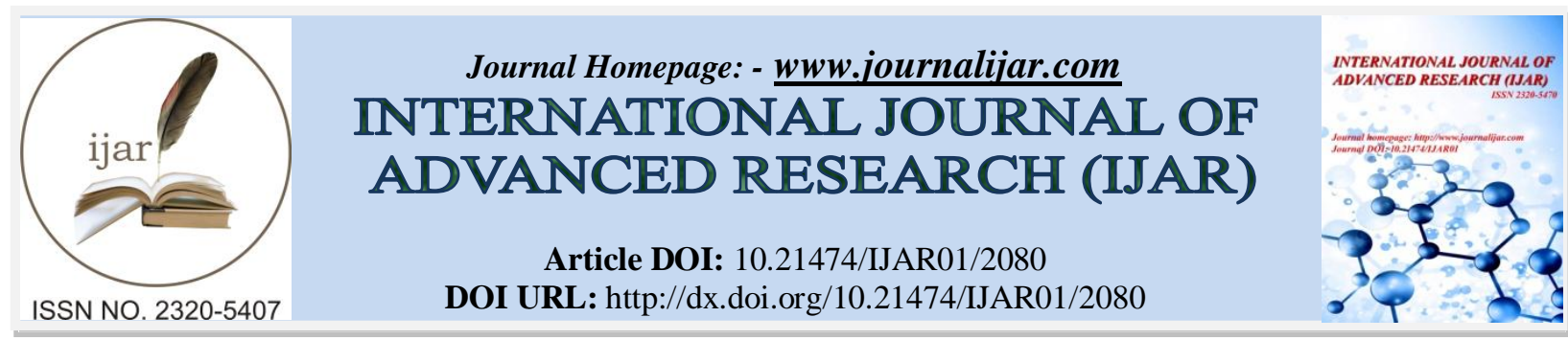

RESEARCH ARTICLE

\title{
EFFECTIVENESS OF GARLIC, ROSEMARY AND GINGER ESSENTIAL OILS ON IMPROVE THE QUALITY AND SHELF LIFE OF BAGRUS BAYAD FISH SAUSAGE PRESERVED BY COLD STORAGE.
}

Shaban Abd El-Halim El-Sherif and Safwat Abd El-Ghafour.

Fish Processing Technology Laboratory, National Institute of Oceanography and Fisheries, Cairo, Egypt.

\section{Manuscript Info}

Manuscript History

Received: 24 September 2016

Final Accepted: 26 October 2016

Published: November 2016

Key words:-

Fish sausage, essential oils, cold storage, quality criteria, and shelf-life

\section{Abstract}

This research was carried out to evaluate the antioxidant activity and antimicrobial effects of individually (1.0\%) garlic (Allium sativum), ginger (Zingiber officinal) and rosemary (Rosmarinus officinalis) essential oils (EOs) as natural preservatives to extend the shelf-life of raw Bayad (Bagrus bayad) fish sausage. Fish sausage treated with tested essential oils and untreated (control sample) were packed in polyethylene bags and stored in refrigerator at $4 \pm 1^{\circ} \mathrm{C}$ for 25 days. The analysis of physico-chemical quality criteria; total volatile basicnitrogen (TVB-N), thiobarbituric acid (TBA) and $\mathrm{pH}$ value, microbiological quality indices; total bacterial count (TBC), psychrophilic bacteria (PCB) and yeast \& mould (YM) counts were carried out on treated and untreated raw fish sausage periodically every 5 days during storage period and sensory analysis performed on fish sausage periodically with chemical and microbiological analysis after frying raw sausage. The obtained results showed that all investigated analysis parameters; (TVB-N), (TBA) and $\mathrm{pH}$ value, (TBC), (PCB) and (YM) counts were gradually increased during storage period in different ratios depending on the kind of tested essential oil, the increases of these parameters were significantly higher $(\mathrm{p}<0.05)$ in control sample than samples treatment with (EOs).The obtained results also showed that there was a significant $(p<0.05)$ enhancement in sensory quality attributes of fish sausage; samples treated with ginger, rosemary and garlic essential oils, respectively. In addition, the shelf-life and the safety storage period for these products were found to be less than 20 days for control sample and more than 25 days of samples treated with EOs under cold storage. In general, the investigated essential oils caused a significant $(p<0.05)$ extending of the shelf-life through retarded the spoilage and enhancement the physico-chemical, microbiological and sensory quality attributes for raw Bayad fish sausage during cold storage. Therefore, The tested EOs had a high effectiveness as antioxidative, antimicrobial and should be utilized for extending the shelf-life and enhancing quality attributes of raw fish sausage during cold storage as follows; sausage samples treated with $1.0 \%$ ginger as the best treatment, followed by samples treated with $1.0 \%$ rosemary and treated with $1.0 \%$ garlic compared with untreated sample. 
Copy Right, IJAR, 2016, All rights reserved.

\section{Introduction:-}

Fish is considered as a valuable part of human nutrition because of its high content of polyunsaturated fatty acids (PUFAs) and protein (Kykkidou et al., 2009); long-chain polyunsaturated fatty acids of these products have gained attention because of their prevention of human cardiovascular diseases (Ozogul et al., 2006). Fish sausage are considered better than beef, pork and chicken sausage because of high marine protein efficiency rate (PER) with low fat content containing long chain $n$-3 fatty acids, beneficial for health (Churi et al., 2016). Fish sausage can be produced by using similar methods and process of meat sausage. Due to changing consumer preferences toward healthier life styles and safer and cheaper foods, sausage manufacturers have turned to meat alternatives such as fish. The addition of fish meat in sausage formulation could improve nutritional quality of the product and can be a way to insert fish meat in human diet. The expansion of the fast-food industry and the increased consumption of processed-meat products make it necessary to reevaluate the quality characteristics of fish sausage products and to be available in the Egyptian market.

Despite fish and fish products have the rapeutic and nutritional value, these products have a short shelf-life, this is due to the vast amounts of free amino acids and volatile nitrogen bases and higher final $\mathrm{pH}$ that limit the useful life of the product being highly susceptible to oxidation of unsaturated fatty acids and this can affect the flavor, taste, texture, aroma, and shelf-life of fish and fish products (Mexis et al., 2009).

To prevent and delay the quality changes caused by lipid oxidation in foods and seafood, various synthetic antioxidants have been used (Benjakul et al. 2005). However, with growing concerns regarding the safety of synthetic antioxidants, natural antioxidants have been suggested as safe alternative to synthetic antioxidants to retard oxidative processes and to improve the keeping quality of fish. This ability is due to their potential as free radical scavengers which may terminate radical chain reactions and display antibacterial effects against bacterial pathogens (Singh et al., 2005). The bacteriostatic effects of spices may occur by two mechanisms: the delay and partial inhibition of DNA and proteins synthesis (Feldberg et al., 1988).

Spices and herbs have been added to food since ancient times, not only as flavoring agents, but also as folk medicine and food preservatives (Nakatani, 1994). Furthermore, certain spices and herbs were used as green materials, plant extracts; essential oils (EOs) and powders for prolong the storage life of foods by preventing rancidity through their antioxidants activity or through bacteriostatic or bactericidal activity, also to food-borne pathogenic bacteria (Shelef et al., 1980). Essential oils (EOs) contain a mixture of compounds, which includes terpenes, alcohols, acetones, phenols, acids, aldehydes, and esters and mainly used as food flavorings or functional components in pharmaceuticals (Corbo et al., 2009).

Garlic (Allium sativum) oil one of the commonly use spices to enhance flavor in food. Apart from it, Allium sativum has a wide spectrum of actions which include antibacterial, antifungal, antioxidant and beneficial effects on the cardiovascular and immune system of human. The presence of allicin, a sulfur-containing compound found in garlic, that enables the antimicrobial effects (Sallam et al. 2004 and Gafar et al., 2012).

Rosemary (Rosmarinus officinalis) oil is well known as a common spice which extensively used in the food industry. Antioxidant efficiency of rosemary extract or oil is due to high content of phenolic compounds; monoterpenes (eteric olis), diterpene phenols (carnosic acid, carnosol, rosmanol, epirosmanol, isorosmanol, methylcarnosate), phenolic acids (rosmarinic acid), flavonols and triterpene acids (ursolic acid, oleanolic acid, butilinic acid) which break free radical chain reactions by hydrogen atom donation (Riznar et al., 2006).

Rhizome of the ginger species, (zinger officinale) is widely used as a spice and food seasoning due to its sweet aroma and pungent taste. It has been known to have antioxidant activity and effective as antimicrobial (Zia-urRehman et al., 2003). Ginger oil inhibits Aspergillus, a fungus known for production of aflatoxin, a carcinogen and contains spectra of biologically active compounds, such as curcumin, 6-gingerol, 6-shagaols, zingiberene, bisabolene and several other types of lipids that confer on it, the properties of being pungent and a stimulant. These compounds are responsible for the unique aroma and flavor of ginger (Akram et al., 2011). Many studies were carried out to prove the effect of combination of refrigeration and essential oils on extending the shelf-life of fish and fish products (Zakipour and Divband, 2012). 
Therefore, this study was carried out to investigate the effect of individually (1\%) garlic, ginger and rosemary essential oils on improve the quality and extending the shelf-life of raw Bayad fish sausage during storage at $4 \pm 1^{\circ} \mathrm{C}$ for 25 days by determination of physico-chemical, microbial and sensory quality criteria so, shelf-life periodically during cold storage.

\section{Materials and methods:- \\ Fish sausage processing:- \\ Fish samples:-}

Fresh Bayad fish (Bagrus bayad), (2800 $\pm 400 \mathrm{~g}$ weight, 52 $\pm 2 \mathrm{~cm}$ long) were obtained from Wadi El-Rayan Lake, El-Fayoum Governorate, Egypt during March, 2016. Fish samples were transported in insulated iceboxes directly to the Laboratory of Fish Processing and Technology in Shakshouk Research Station, National Institute of Oceanography and Fishers (NIOF). Fayoum Governorate.

\section{Ingredients:-}

sunflower oil, spices mixture, corn starch, $\mathrm{NaCl}$ and sugar were obtained from local market and sodium polyphosphate (Merck Co., Germany).The essential oils (EOs); garlic (Allium sativum), ginger (Zingiber officinal) and rosemary(Rosmarinus officinalis) were obtained from Kato Aromatic Co., Giza. Casings; mutton casings used for stuffing sausage were purchased from local market in Atabba, Cairo.

\section{Fish mince preparation:-}

The fish samples were beheaded, gutted and washed with tap water to remove all viscera, black membranes, swim bladder and blood. Skin and bones were manually removed to produce pure fillets. The yield of flesh was about $48 \%$.The fillets were dipped in $1.0 \%$ chilled brine solution contained $0.5 \%$ acetic acid for 5 min. (to clean and remove any fishy odor) and fillets were drained. The drained fillets were cut and minced by a kitchen meat mincer using a $3 \mathrm{~mm}$ diameter holes plate.

\section{Preparation of fish sausage:-}

The formulation used in the production of fish sausage is given in Table 1. The minced fish meat was mixed with all other ingredients till obtained homogenized sausage batter; the batter was subdivided into four parts;(1) control without treatment with EOs (2) blended with 1.0\% garlic, (3) blended with $1.0 \%$ ginger and (4) blended with $1.0 \%$ rosemary EOs (EOs were substituted with sunflower oil), then every treatment was mixed well and stuffed into natural casings (from sheep) with diameter $1.5 \mathrm{~cm}$, by using manual filler and punched to pieces of about $10 \mathrm{~cm}$ long. All fresh (raw) fish sausage samples were packed in polyethylene bags and kept in a refrigerator at $4 \pm 1^{\circ} \mathrm{C}$ for 25 days and physico-chemical, microbial and sensory attributes analysis were carried out immediately after preparation (0), 5, 10, 15, 20 and 25 days of storage.

Table 1:- Formulation of fish sausage.

\begin{tabular}{|l|l|l|l|l|l|}
\hline Ingredients & $\mathrm{g} / \mathrm{kg}$ & $\%$ & Spices mixture & $\mathrm{g}$ & $\%$ \\
\hline Minced fish meat & 700 & 70.0 & Black pepper & 4.80 & 32.0 \\
Sunflower oil & 45 & 4.5 & Red pepper & 1.20 & 8.0 \\
Corn starch & 80 & 8.0 & Cardamom & 2.25 & 15 \\
$\mathrm{NaCl}$ & 25 & 2.5 & Coriander & 3.37 & 22.5 \\
Onion & 20 & 2.0 & Cumin & 2.25 & 15 \\
Sodium polyphosphate & 1.7 & 0.17 & Cloves & 0.60 & 4 \\
Sugar & 3.3 & 0.33 & Cubeb & 0.53 & 3.5 \\
Ice water & 100 & 10.0 & & & \\
Spices mixture & 15 & 1.5 & & & \\
Essential oils & 10 & 1.0 & & & \\
\hline Total & 1000 & 100 & Total & 15.00 & 100 \\
\hline
\end{tabular}

\section{Analytical methods:-}

\section{Proximate composition:-}

The proximate composition of raw fish minced and fish sausage were determined according to the AOAC (2006). The crude protein and crude lipid contents were measured by Kjeldahl and Soxhlet methods respectively. The ash 
content was determined by ashing the samples overnight at $550^{\circ} \mathrm{C}$. The moisture content was determined by drying the samples overnight at $105^{\circ} \mathrm{C}$ and the carbohydrate content was calculated by computing the difference.

\section{Quality criteria:-}

Total volatile basic nitrogen (TVB-N) was determined by the Macro distillation method proposed by Pearson (1991). Thiobarbituric acid values (TBA) were determined spectrophotometrically according to the procedure described by Siu and Draper (1978). TBA content was expressed as mg of malonaldehyde (MDA)/kg sample. The $\mathrm{pH}$ value was measured by using standard methods, AOAC (2006).

\section{Microbiological analysis:-}

The samples of raw fish minced and fish sausage were analyzed for microbial profile using standard procedures (APHA, 1992) for total bacterial count(TBC) $\left(30^{\circ} \mathrm{C}, 3\right.$ days) and Psychrophilic bacteria (PCB) $\left(7^{\circ} \mathrm{C}, 10\right.$ days) on plate count agar, yeast \& mold (YM) counts on potato dextrose agar $\left(21^{\circ} \mathrm{C}, 5\right.$ days). The results were expressed as $\log _{10} \mathrm{cfu} / \mathrm{g}$ of sample.

\section{Sensory evaluation:-}

Sensory properties including color, taste, odor, texture and overall acceptability of fried fish sausage by deep-frying in sunflower oil at $160^{\circ} \mathrm{C}$ for $7 \mathrm{~min}$. (frying was carried out immediately during evaluation) were evaluated at zero time immediately after preparation and periodically every five days with chemical and microbiology analysis of raw sausage according to El- Sherif (2001) using the following numerical system: excellent 8.6 - 10,very good 7.6 - 8.5, good 6.6 - 7.5, accepted $5.0-6.5$, poor $4-4.9$ and very poor $0-3.9$.

\section{Statistical Analysis:-}

Least significant difference test (L.S.D) at $(\mathrm{p}<0.05)$ and Standard Error (Mean \pm SE) were carried out on the obtained data of the physico-chemical, microbiological and sensory evaluations as the mean of three replicates (Gomez and Gomez, 1984).

\section{Results and Discussion:- \\ Proximate composition of raw Bayad fish minced and sausage treated and untreated with some essential oils (EOs):-}

Mean values for the proximate chemical composition of fresh raw fish minced and fresh (raw) sausage are given in Table 2. For raw fillets; the moisture, crude protein, fat, ash and carbohydrates contents were 77.34, 17.40, 3.07, 2.10 and $0.09 \%$, respectively. Meanwhile, the corresponding values in raw fish sausage were 67.17- 68.30, 16.4916.85, 7.43-7.56, 1.99-2.44 and 5.66- 6.09\% (on wet basis), respectively. From these results, it could be observed that the investigated fish is a good source of manufacturing fish sausage because belonged to high protein content (15-20\%) (Stansby, 1982) and the big size of fish gave high filleting yield (48\%) indicating that fish sausage that healthier than traditional meat sausage particularly due to the presence long chain n-3 fatty acids and protein (Oliveira et al., 2014).

On the other hand, it could be noticed that the moisture content of raw fish sausage was decreased when compared to the mince fish meat, this reduction after processing may be due to the ingredients which were added to the mince fish. The relative increase in fat, ash and carbohydrates in fish sausage might be attributed to the addition of starch, fat and salt and other ingredients in the preparation of the sausage while the decrease in protein content may be due to the degradation of protein (Ahmed and Elhaj, 2011). It is clear from the present results that parameters chemical composition in raw fish sausage were not affected by inclusion of the plant essential oils as there were no significant different $(\mathrm{p}<0.05)$ between their means and those of control. These results are nearly accordance with obtained by Elagba et al. (2010), who found that Bagrus bayad contains $76 \%$ moisture, $18.48 \%$ crude protein, $3.17 \%$ crude fat and 2.35\% ash and Adam Suleiman et al. (2011) reported that the yield of mince from Bagrus bayad was 46.88\%. Also, Gomma (2005) found that chemical composition of raw catfish and tilapia sausage were 69.57 and 69.21 moisture, 18.98 and 17.95 protein, 3.57and 4.72 fat, 1.66 and 1.88 ash and 6.22 and $6.24 \%$ carbohydrates, respectively. Also, these results are in agreement with found by Huda et al. (2012) and Churi et al. (2016). 
Table 2:- Chemical composition of fresh Bayad fish minced and fish sausage treatment with EOs (On wet basis)

\begin{tabular}{|l|l|l|l|l|l|}
\hline Source & moisture & Protein & Fat & Ash & Carbohydrates \\
\hline Raw fish fillets & $77.34 \pm 0.88$ & $17.40 \pm 0.15$ & $3.07 \pm 0.21$ & $2.10 \pm 0.07$ & $0.09 \pm 0.02$ \\
\hline Raw sausage & & & & & \\
Control & $67.78 \pm 1.02$ & $16.53 \pm 0.05$ & $7.47 \pm 0.14$ & $2.43 \pm 0.08$ & $5.79 \pm 0.80$ \\
Garlic & $67.17 \pm 0.60$ & $16.85 \pm 0.42$ & $7.45 \pm 0.03$ & $2.44 \pm 0.20$ & $6.09 \pm 1.06$ \\
Ginger & $68.30 \pm 0.11$ & $16.49 \pm 0.15$ & $7.56 \pm 0.09$ & $1.99 \pm 0.03$ & $5.66 \pm 0.07$ \\
Rosemary & $68.13 \pm 0.92$ & $16.56 \pm 0.09$ & $7.34 \pm 0.11$ & $2.26 \pm 0.03$ & $5.71 \pm 0.07$ \\
L.S.D. at 5\% & 1.22 & 0.55 & 0.62 & 0.51 & 0.85 \\
\hline
\end{tabular}

Means values of 3 replicates \pm standard error. Means values are not significant different $(\mathrm{p}<0.05)$.

\section{Physico-chemical changes of raw Bayad fish sausage during storage at $4 \pm 1{ }^{\circ} \mathrm{C}$ as affected by essential oils (EOs):-}

Total volatile basic-nitrogen (TVB-N) content:-

The impact of the individual tested essential oils; (1.0\%) ginger, rosemary and garlic oils on TVB-N values of cold stored fish sausage was showed in Figure 1, there were significant differences $(p<0.05)$ in TVB-N values between treated fish sausage samples with essential oils and the control (untreated with EOs) at the beginning of storage. It is clear from the present results that at the beginning of the storage, TVB-N value was $11.60 \mathrm{mg} / 100 \mathrm{~g}$ (on wet basis) for control sausage samples while, were $10.0,7.8$ and $8.3 \mathrm{mg} / 100 \mathrm{~g}$ for samples treated with garlic, ginger and rosemary oils, respectively.

During cold storage, the significant $(\mathrm{p}<0.05)$ increasing pattern in TVB-N values was observed in all investigated fish sausage samples. This may be attributed to the breakdown of proteins as a result of activity of microbial strains and proteolytic enzymes (Yassin and Abo-Taleb, 2007). The highest significant $(\mathrm{p}<0.05)$ incremental of TVB-N value was recorded in control sample. The treatments with ginger, rosemary and garlic oils respectively, were more effective in delaying the rate of TVB-N increase during the cold storage period. This may be attributed to the role of such oils on microbial population and bacterial growth as antimicrobial agents (Sacchetti et al., 2005). At the end of cold storage period, the TVB-N values for all samples except control did not exceed the acceptable limit stipulated and mentioned by EES (1991) and EOS (2005) they stated that $20 \mathrm{mg}$ TVB-N/100g raw samples indicates the spoilage of fish sausage and minced meat. Thus, control sample of investigated fish sausage considered spoiled $(22.15 \mathrm{mg} / 100 \mathrm{~g})$ at 20 days of storage while, garlic (18.56), rosemary (16.88) and ginger sample $(15.45 \mathrm{mg} / 100 \mathrm{~g})$ were not exceed the acceptable limit at the end of storage period ( 25 days). The formation of TVB-N is generally associated with the activity of micro-organisms and the formation tends to be increase at high microbial population (Chytiri et al., 2004). This finding proves the effect of EOs in reduction of the bacterial growth then, TVB-N.

From results; ginger, rosemary and garlic essential oils were the high effective of Bayad fish sausage in delaying the rate of TVB-N increase, as well as in prolonging the shelf-life of fish sausage throughout the subsequent cold storage (at $4 \pm 1^{\circ} \mathrm{C}$ for 25days) and treatments with EOs could be arranged descending according to the reduced levels of TVB-N as follows: fish sausage treated with $1.0 \%$ ginger, $1.0 \%$ rosemary and $1.0 \%$ garlic respectively. These results are in agreement with reported by Gomma (2005), Ali et al. (2010), Osheba et al. (2010) and Özpolat et al. (2014). 


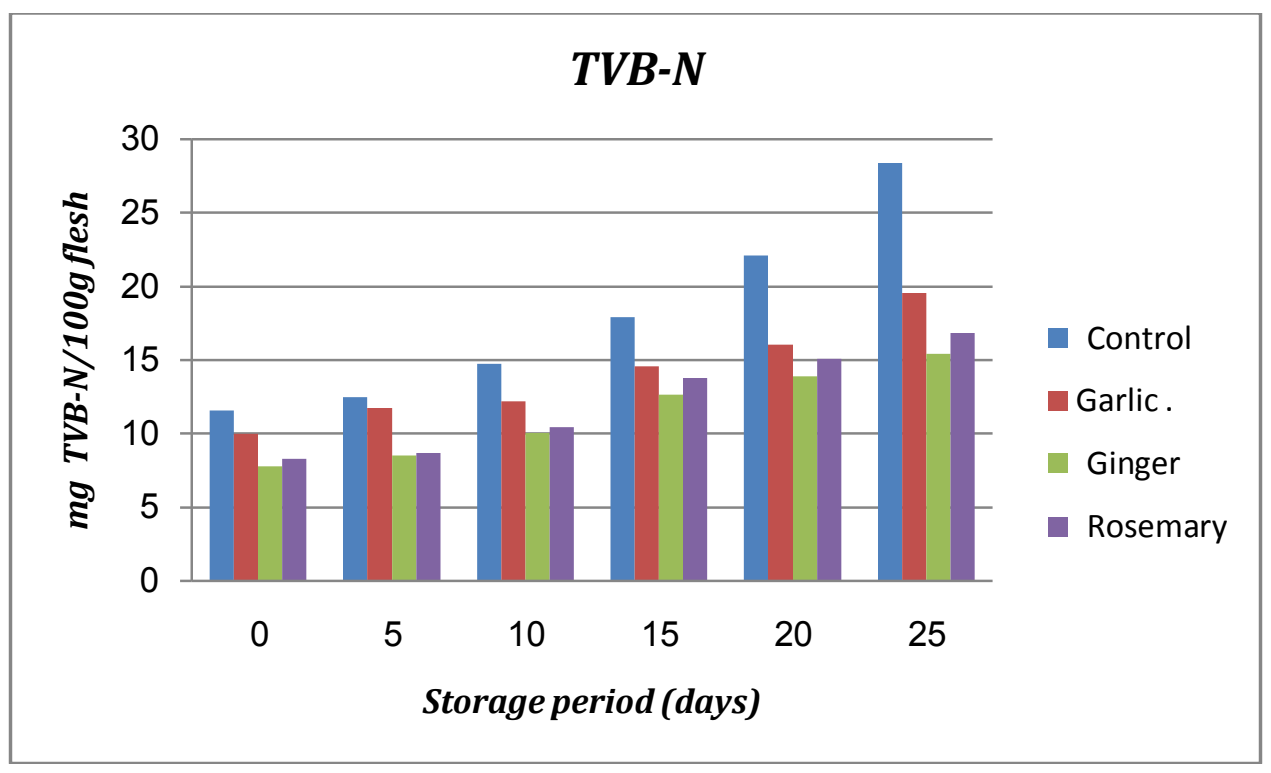

Figure 1:- Changes in total volatile basic-nitrogen (TVB-N) content $(\mathrm{mg} / 100 \mathrm{~g}$ flesh) of fish Sausage during storage (at $4 \pm 1^{\circ} \mathrm{C}$ for 25 days) as affected by treatment with EOs

\section{Thiobarbeturic acid (TBA) value:-}

The influence of individually (1.0\%) ginger, rosemary and garlic essential oils treatments on the TBA values of Bayad fish sausage during cold storage at $4 \pm 1^{\circ} \mathrm{C}$ for 25 days was investigated. The obtained results are shown in Fig. 2. It could be noticed that immediately after preparation (at zero time of storage) there were no significant $(\mathrm{p}<0.05)$ differences between the control and other treated samples. The highest value of TBA was found in untreated fish sausage sample; control $(0.45 \mathrm{mg}$ malonaldehyde (MDA) $/ \mathrm{kg}$ flesh), while the lowest value was recorded in samples treated with ginger $(0.26 \mathrm{mg} \mathrm{MDA} / \mathrm{kg})$ followed by samples treated with rosemary $(0.38 \mathrm{mg}$ MDA) and garlic $(0.40 \mathrm{mg} \mathrm{MDA} / \mathrm{kg})$ essential oils. These values of TBA were increased $(\mathrm{p}<0.05)$ to $3.48,1.23$, 1.85 and $2.05 \mathrm{mg} \mathrm{MDA} / \mathrm{kg}$ flesh, respectively at the end of storage period (25 days).

Therefore, although the $1.0 \%$ ginger, $1.0 \%$ rosemary and $1.0 \%$ garlic EOs had significant $(\mathrm{p}<0.05)$ reduction effect on the TBA values, there was an increasing in TBA values in all different fish sausage samples throughout the cold storage by different rates affecting by kind of essential oil and cold storage period. The incremental in TBA values for all fish sausage samples with advancing the cold storage time may be due to the auto-oxidation of fats, bacteriological and/or oxidative rancidity. Thus, the control sample considered spoiled at 20 days of storage (2.15 mg MDA) and sample treated with garlic (2.05 mg MDA) spoiled at 25 days as reported by Suman et al. (2010) who indicate that TBA values of $2 \mathrm{mg} \mathrm{MDA} / \mathrm{kg}$ flesh or greater in meat such as beef are considered to be rancid and Bonnel (1994) mentioned that fish and fish products of good quality will have TBA value less than $2 \mathrm{mg}$ MDA/kg flesh, while poorer quality fish will have $3-27 \mathrm{mg} \mathrm{MDA} / \mathrm{kg}$. Accordingly, the sausage samples treated with ginger or rosemary in the present study would not deceive consumers up to 25 days of storage.

Finally, the obtained results indicated that the treatment of Bayad fish sausage with $1.0 \%$ ginger, $1.0 \%$ rosemary and $1.0 \%$ garlic EOs, respectively led to extension $(\mathrm{p}<0.05)$ of their shelf-life comparing with the control sample. Also, several studies were reported the effect of addition essential oils to food products on the reduction of TBA values (Kassem et al., 2011) and Erkan et al. (2011) found that the use of thyme (1.0\%) and laurel essential oil (1.0\%) was extended the shelf-life of bluefish minced by about 3-4 days. These results are in agreement with previous studies by Sallam et al. (2004), Abou-Taleb et al. (2007) and Ucak et al. (2011). 


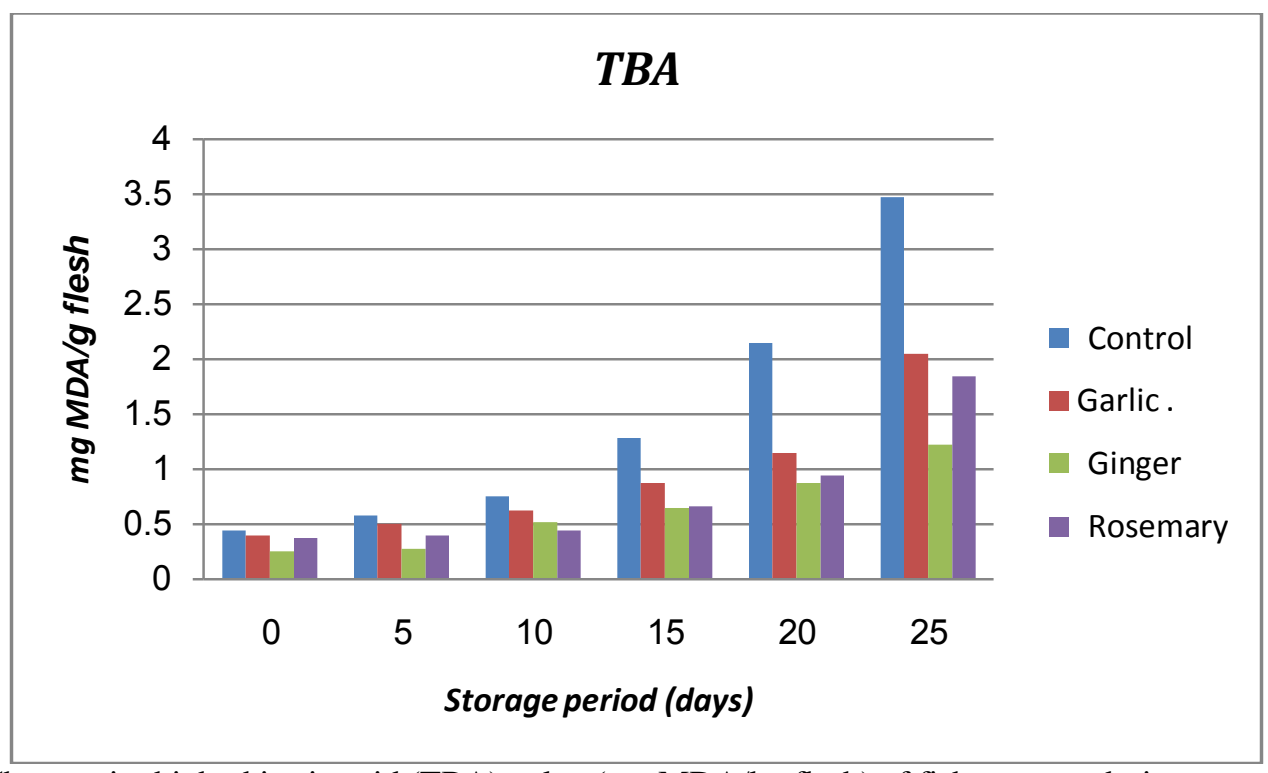

Figure 2:- Changes in thiobarbituric acid (TBA) value (mg MDA/kg flesh) of fish sausage during storage at $\left(4 \pm 1^{\circ} \mathrm{C}\right)$ as affected by treatment with EOs

\section{pH value:-}

Changes in $\mathrm{pH}$ value of different Bayad fish sausage during cold storage at $4 \pm 1{ }^{\circ} \mathrm{C}$ are shown in Fig. 3. The differences in $\mathrm{pH}$ means values between different treated and untreated samples were insignificant $(\mathrm{P}<0.05)$ at zero time of storage, the initial $\mathrm{pH}$ values of the control and samples treated with individually (1.0\%) garlic, ginger and rosemary EOs were $6.23,6.21,6.15$ and 6.18 , respectively. Also, the results showed a significant $(\mathrm{P}<0.05)$ increase in $\mathrm{pH}$ values in all sausage samples during storage period by different rates, the highest incremental rates ( $\mathrm{pH}$ value) was found in control sample reached to value of 6.94 at the end of storage period compared with samples treated with garlic, ginger and rosemary EOs which reached to 6.46, 6.30 and 6.42, respectively. This reduction in $\mathrm{pH}$ values of samples treated with EOs compared with control indicates the effectiveness of these EOs as an antimicrobial agent so, it can be used as a way of combating the growth of common microorganisms causes of food poisoning (Fisher and Phillips, 2006).The increase in $\mathrm{pH}$ values of all samples treated with (1.0\%) garlic, ginger and rosemary EOs and untreated during the storage period due to the protolytic enzymes that hydrolyzed fish protein to simple proteins, polypeptides and amino acids which were nutritious intermediate compounds as reported by Khallaf (1990). These results are in agreement with reported by Salem et al. (2010) and Özpolat et al. (2014).

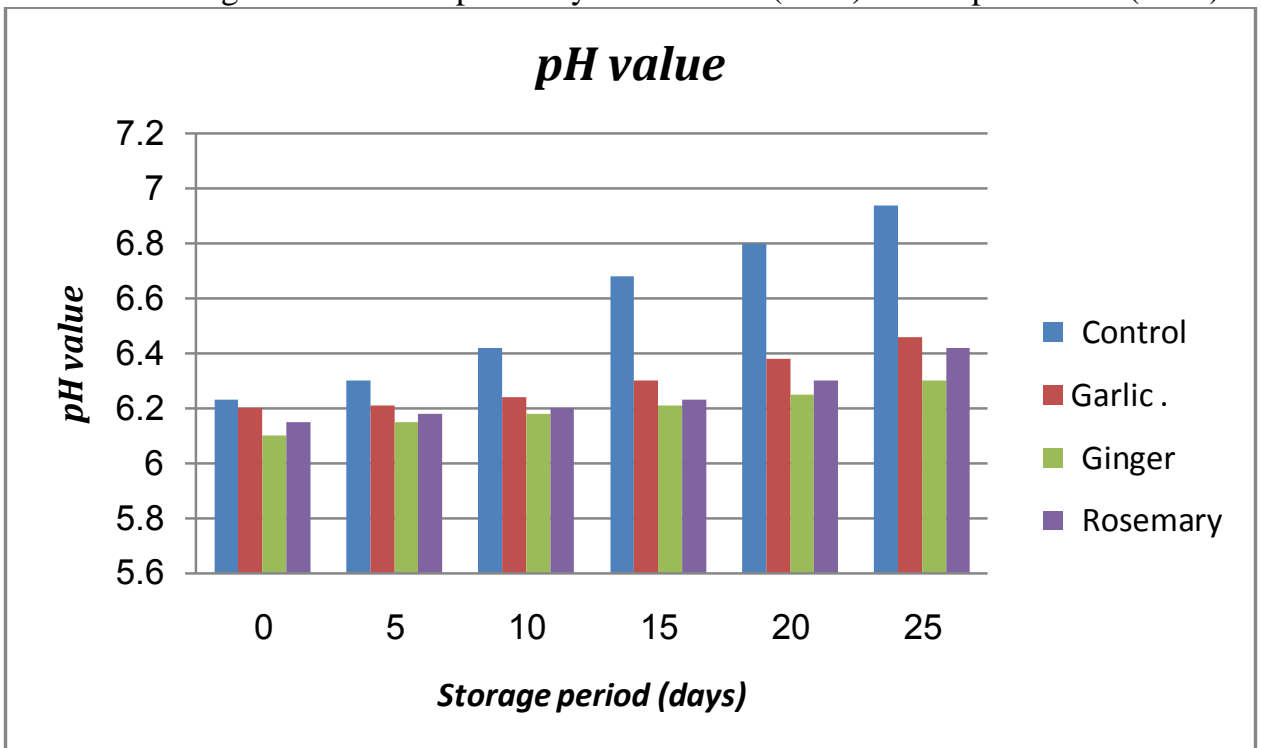

Figure 3:- Changes in $\mathrm{pH}$ values of fish sausage during cold storage at $\left(4 \pm 1^{\circ} \mathrm{C}\right)$ as affected by treatment with EOs 


\section{Microbiological load changes of raw Bayad fish sausage during storage at $4 \pm 1{ }^{\circ} \mathrm{C}$ as affected by essential oil} (EOs):-

Total bacterial count (TBC):-

Fig. 4 shows the changes of total bacterial count of different raw fish sausage samples during cold storage as affected by addition of $1.0 \%$ garlic, $1.0 \%$ ginger and $1.0 \%$ rosemary EOs individually. At zero time of storage, control samples (untreated with EOs) showed the highest mean counts of TBC comparing to other samples treated with essential oils of garlic, ginger and rosemary that caused a significantly $(\mathrm{p}<0.05)$ reduction in microbial count of treated fish sausage immediately after preparation. The TBC of control and treatment samples with EOs fish sausage were gradually increased significantly $(\mathrm{p}<0.05)$ during storage at $4 \pm 1^{\circ} \mathrm{C}$ with a highly increase in control and depending on the kind of EOs. This increase may be due to the growth of psychrophilic bacteria under this storage condition as reported by Osheba et al. (2010).TBC (log cfu/g flesh) of control sample were 3.25 at zero time of storage increased to $7.65 \log \mathrm{cfu} / \mathrm{g}$ sausage sample at the end of storage period (25 days), while samples treated with garlic, ginger and rosemary EOs were 2.45, 2.60 and 3.02 at zero time increased to $4.65,3.70$ and $4.00 \mathrm{cfu} \mathrm{g}$ ${ }^{1}$ respectively. This mentioned that garlic, ginger and rosemary EOs contain the phenolic compounds such as Timol, Carvacol, acid 1, 8 Cafeic and Transcinnam aldehyde responsible for the antibacterial properties (Salvat et al., 2001).

Also, it could be detected that a significant differences $(\mathrm{P}<0.05)$ between the different oils were noticed, ginger have strong inhibitory effect against the growth of TBC followed by rosemary and garlic EOs. In our study the raw fish sausage of control sample was considered accepted until $20^{\text {th }}$ day of storage and were rejected because TBC count was exceeded than the maximum permissible level MPL $\left(10^{6}\right.$ numbers/g) was reported the acceptable limit of TBC for sausage (Sekin and Karagozoglu, 2004), also MPL recommended by the International Commission on Microbiological Specifications for TBC in all sausage products is below $7 \log _{10} \mathrm{cfu} / \mathrm{g}$ sample (ICMSF, 2002), while the other fish sausage samples treated with EOs remained acceptable microbiologically and safe for consumption up to 25 days storage at $4 \pm 1^{\circ} \mathrm{C}$ because the values were below the MPL. This antimicrobial activity of these essential oils could be resulted from the hydrophobic nature which enables them to partition in the lipids of the bacteria cell membrane and mitochondria, disturbing the structures and rendering it more permeable (Sikkema et al., 1994).

Therefore this study demonstrated that the use of $(1.0 \%)$ essential oils of garlic, ginger and rosemary reduced the microbial load of raw Bayad fish sausage during cold storage period compared to the control. These results are in agreement with found by Badee et al. (2013), Özpolat et al. (2014) and Babatunde and Adewumi (2015).

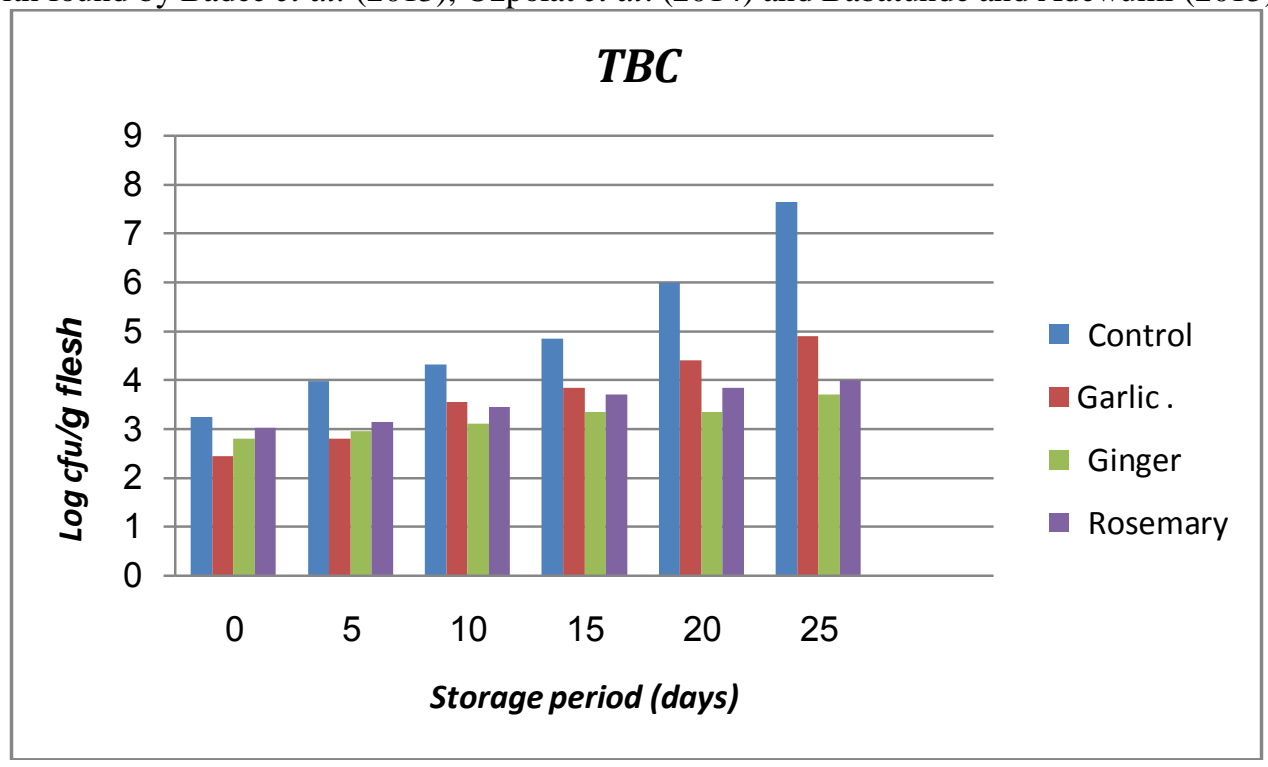

Figure 4:- Changes in total bacterial count (TBC) load (log cfu/g flesh) of fish sausage during storage (at $4 \pm 1^{\circ} \mathrm{C}$ for 25 days) as affected by treatment with EOs

Psychrophilic bacteria (PCB) count:-

The psychrophilic bacteria are well known as the main cause of spoilage of refrigerated fish. Therefore, the inhibitory effect of individually $(1.0 \%)$ garlic, ginger and rosemary EOs on psychrophilic bacteria growth in Bayad fish sausage during cold storage (at $4 \pm 1^{\circ} \mathrm{C}$ for 25 days) was determined. As shown in Fig. (5) control; Bayad fish 
sausage sample untreated with any tested essential oil had the highest count of PCB along cold storage period compared to other treatments. The obtained results point to garlic followed by ginger and rosemary EOs have strong inhibitory effects against the growth of PCB which reduced significantly $(\mathrm{p}<0.05)$ immediately at zero time from $2.85 \mathrm{log} \mathrm{cfu} \mathrm{g}^{-1}$ for the control sample to $2.40,2.10$ and $1.45 \log \mathrm{cfu} \mathrm{g}^{-1}$ for fish sausage samples treated with rosemary, ginger and garlic EOs, respectively. Also as reported in TBC, PCB counts were gradually increased for all fish sausage samples during cold storage and the control sample was highest $(\mathrm{p}<0.05)$ count until the final of storage period. As demonstrated, the treated samples with ginger, rosemary and garlic oils respectively showed the lowest counts in PCB at the final of cold storage.

Therefore, ginger oil was observed to possess high antimicrobial activity followed by rosemary and garlic oils in immediate reduction of bacterial population, where the low effectiveness of garlic oil in comparison with ginger and rosemary oils could be attributed to the losses of volatile sulfur compounds, which have high biological activity, during distillation, and also due to the nature of garlic oil itself, which is volatile and hydrophobic (Sallam et al., 2004). Also, Gonza'lez-Fandos (1996) reported that garlic could differentially inhibit bacteria; lactic acid bacteria are the least sensitive microorganisms, and garlic can stimulate the growth of these bacteria by providing them with a carbohydrate source. These results are in accordance with that of Osheba et al. (2010) and Özpolat et al. (2014).

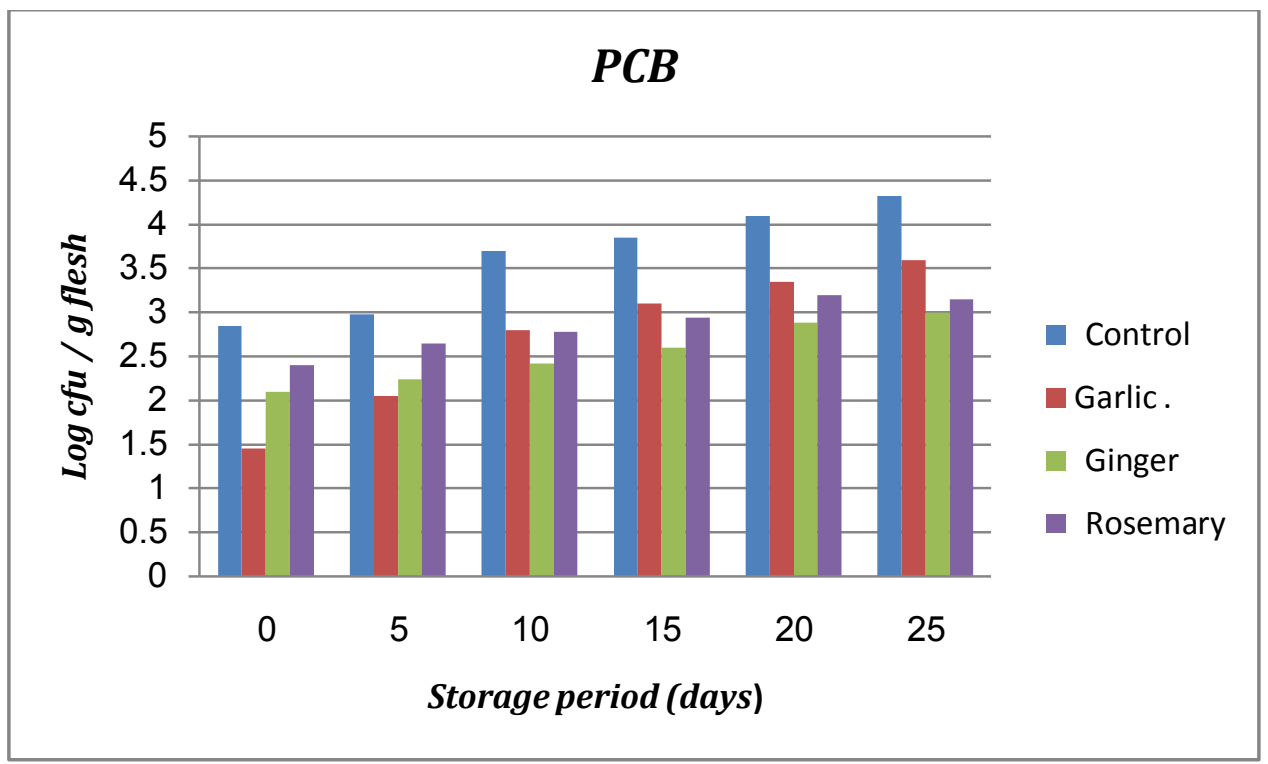

Figure 5:- Changes in Psychrophilic Bacteria (PCB) count (log cfu/g flesh) of Bayad fish sausage during cold storage (at $4 \pm 1^{\circ} \mathrm{C}$ for 25 days) as affected by treatment with EOs

Yeast \& Mold (YM) counts:-

Fig. 6 shows the changes in the yeast and mold of the different types of Bayad fish sausage during refrigerated storage at $4 \pm 1^{\circ} \mathrm{C}$ affected by addition individually (1.0\%) garlic, ginger and rosemary EOs at preparation. YM counts were not detected in any of sausage samples at the $0^{\text {th }}$ day until $4^{\text {th }}$ day of storage. YM counts were detected in control samples $\left(1.85 \log \mathrm{cfu} \mathrm{g}^{-1}\right)$ at $5^{\text {th }}$ day. In treated sausage samples with EOs, it could be noticed that YM counts were appeared at the $10^{\text {th }}$ day in samples treated with ginger $\left(1.22 \log\right.$ cfu g $\left.{ }^{-1}\right)$, rosemary $\left(1.64 \log \mathrm{cfu} \mathrm{g}^{-1}\right)$ oils and at $15^{\text {th }}$ day in samples treated with garlic $\left(1.20 \log \mathrm{cfu} \mathrm{g}^{-1)}\right.$ oil.

On the other hand, YM counts were gradually increased for all fish sausage samples during cold storage as noticed in Figure 6 and a highly significant differences $(\mathrm{P}<0.05)$ between the control sample and other samples treated with EOs were noticed thus, the control sample was highest $(\mathrm{p}<0.05)$ count until the final of storage period. At the end of storage period, YM counts reached to $4.00 \mathrm{log} \mathrm{cfu} \mathrm{g}^{-1}$ of control sausage samples, while 2.15, 2.55 and 2.90 of samples treated with garlic, ginger and rosemary oils respectively. Therefore, the sausage sample treated with garlic oil was the lowest YM counts followed by samples treated with ginger and rosemary oils compared with control sample, this indicated that tested EOs especially garlic oil have stronger effects against the growth of yeast and molds than ginger and rosemary oils in reduction of yeast and molds population. 
So, the additions of essential oils to fish sausage were extended product shelf life ( 25 day) compared to the control (20 day). Similar results were found by Erkan et al. (2011) who reported that the use of thyme (1.0\%) and laurel essential oil (1.0\%) extends the shelf life of bluefish during storage in ice by about 3-4 days. These results are in agreement with reported by Osheba et al. (2010), Iheagwara (2013) and Özpolat et al. (2014).

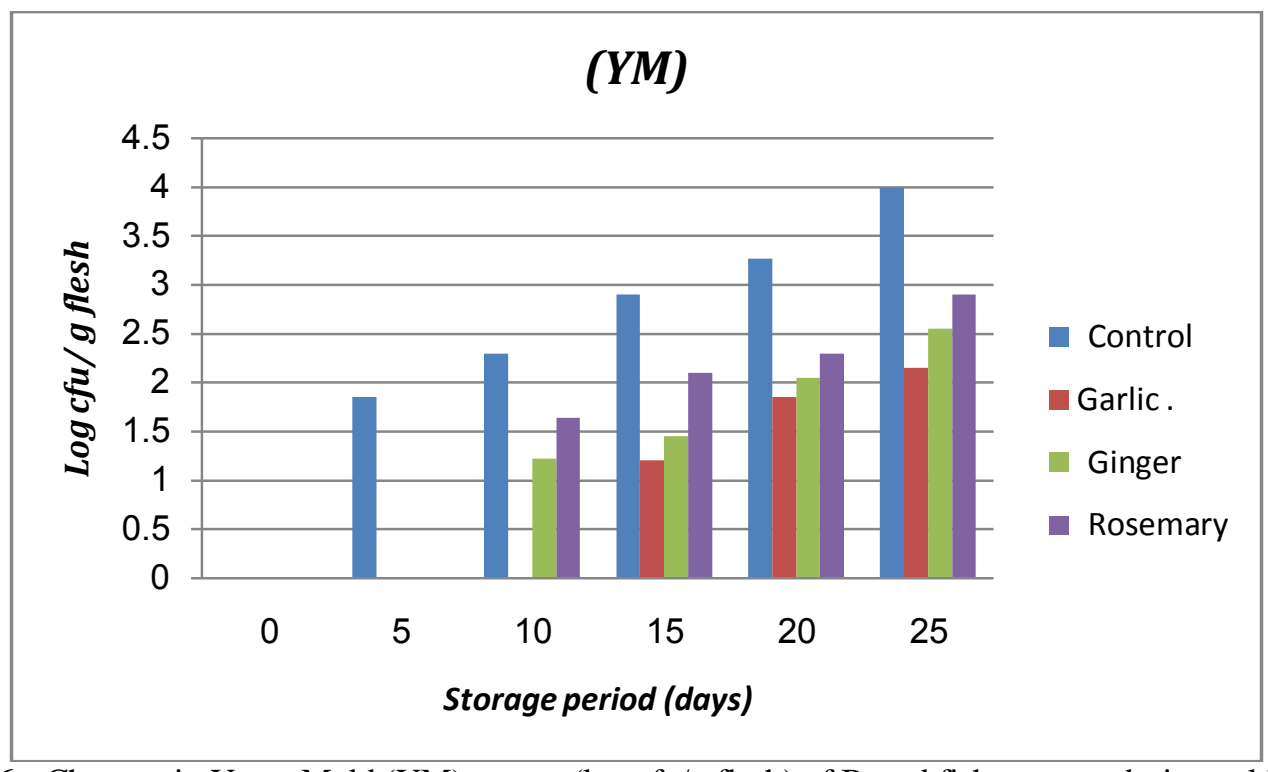

Figure 6:- Changes in Yeast-Mold (YM) counts (log cfu/g flesh) of Bayad fish sausage during cold storage (at $4 \pm 1^{\circ} \mathrm{C}$ for 25 days) as affected by treatment with EOs

\section{Sensory properties changes of Bayad fish sausage during cold storage at $\left(4 \pm 1^{\circ} \mathrm{C}\right)$ as affected by essential oils (EOs):-}

The results of sensory analysis are one of the most important quality criteria used for determination of shelf life of seafood. The changes of sensory properties (taste, color, odor, texture and general acceptability) of fried Bayad fish sausage treated individually with $1.0 \%$ garlic, $1.0 \%$ ginger and $1.0 \%$ rosemary EOs and untreated (control) during cold storage at $\left(4 \pm 1^{\circ} \mathrm{C}\right)$ were recorded in Table (3). It could be found that Bayad fish sausage treated with EOs had excellent scores for all sensory parameters immediately after preparation (at zero time of storage) with the presence of some garlic odor and no found significant $(\mathrm{p}<0.05)$ differences between them till 10 days of storage, then a significant $(\mathrm{p}<0.05)$ differences were found until the end of storage period. While, fish sausage control had excellent scores for color and texture then very good scores for flavor (taste and odor) immediately after preparation. After that, all sensory parameters scores for treated and untreated sausage samples were decreased gradually with prolongation the storage period.

Therefore, a noticeable significant $(\mathrm{p}<0.05)$ difference could be observed between samples treated with EOs and control in the case of taste and odor characteristics during the storage period. EOs was found to have an added advantage in terms of their synergistic effect against oxidation and in enhancing the taste and odor. The decline in overall acceptability of control samples as a result of this difference in taste and odor was more prominent during 15-20 days of storage and the off flavor formation was occurred. While, there was no marked difference $(\mathrm{p}<0.05)$ between the EOs treated samples and control in color and texture during zero time till 10 days of storage then, a significant $(\mathrm{p}<0.05)$ difference was found until the end of storage period.

On the other hand, the taste, color, odor, texture and overall acceptability scores of control sample reached to 4.0, $4.5,4.5,4.2$ and 4.2, respectively by 20 days of storage which was below the acceptable limit of score (5) and was greatly deteriorated being undesired as softening of texture and off odors was appeared then, this product become rejected for consumers. In the case of the other samples treated with EOs, the scores were above of acceptable limit (5) even after the end of storage period ( 25 days). Hence, the scores of overall acceptability garlic, ginger and rosemary samples were 5.3, 6.5 and 5.8 respectively at the end of storage period ( 25 days) and was in the order samples, ginger > rosemary $>$ garlic. 
Therefore, Bayad fish sausage samples treated with $1.0 \%$ ginger showed the significant $(\mathrm{p}<0.05)$ highest mean score of overall acceptability followed by samples treated with $1.0 \%$ rosemary and treated with $1.0 \%$ garlic compared with untreated samples (control) which rejected before 20 days of cold storage. Even through the added EOs delayed oxidation and extending the shelf-life, their antioxidant activity reduced during storage by increase significantly $(\mathrm{p}<0.05)$ differences in all individual tested samples during the end of storage periods.

Table 3:- Changes in sensory properties of fish sausage during cold storage (at $4 \pm 1^{\circ} \mathrm{C}$ for 25 days) as affected by EOs

\begin{tabular}{|c|c|c|c|c|c|}
\hline \multirow[t]{2}{*}{ Storage period (days) } & \multicolumn{5}{|c|}{ Treatments; } \\
\hline & Control & Garlic & Ginger & Rosemary & L.S.D. at 5\% \\
\hline \multicolumn{6}{|l|}{ Taste } \\
\hline 0 & $7.5 \pm 0.01$ & $9.0 \pm 0.00$ & $9.5 \pm 0.02$ & $9.0 \pm 0.11$ & 0.61 \\
\hline 5 & $7.2 \pm 0.05$ & $8.8 \pm 0.03$ & $9.2 \pm 0.00$ & $9.0 \pm 0.03$ & 0.55 \\
\hline 10 & $7.0 \pm 0.02$ & $8.5 \pm 0.03$ & $8.8 \pm 0.04$ & $8.5 \pm 0.05$ & 1.02 \\
\hline 15 & $6.0 \pm 0.06$ & $7.0 \pm 0.02$ & $8.0 \pm 0.02$ & $7.5 \pm 0.00$ & 0.80 \\
\hline 20 & $4.0 \pm 0.00$ & $6.5 \pm 0.11$ & $7.5 \pm 0.00$ & $7.0 \pm 0.11$ & 0.35 \\
\hline 25 & $3.5 \pm 0.12$ & $5.2 \pm 0.05$ & $6.5 \pm 0.13$ & $6.0 \pm 0.12$ & 0.50 \\
\hline L.S.D. at 5\% & 0.80 & 0.58 & 0.76 & 0.80 & \\
\hline \multicolumn{6}{|l|}{ Color } \\
\hline 0 & $8.8 \pm 0.05$ & $8.6 \pm 0.03$ & $9.0 \pm 0.11$ & $9.0 \pm 0.04$ & 1.05 \\
\hline 5 & $8.5 \pm 0.02$ & $8.5 \pm 0.07$ & $9.0 \pm 0.09$ & $9.0 \pm 0.06$ & 0.82 \\
\hline 10 & $7.7 \pm 0.00$ & $8.0 \pm 0.03$ & $8.7 \pm 0.09$ & $8.6 \pm 0.04$ & 1.02 \\
\hline 15 & $6.5 \pm 0.01$ & $7.6 \pm 0.06$ & $8.5 \pm 0.02$ & $8.0 \pm 0.08$ & 0.67 \\
\hline 20 & $4.7 \pm 0.00$ & $7.0 \pm 0.08$ & $7.5 \pm 0.00$ & $7.0 \pm 0.01$ & 0.88 \\
\hline 25 & $4.0 \pm 0.06$ & $6.0 \pm 0.13$ & $6.8 \pm 0.05$ & $6.5 \pm 0.02$ & 0.12 \\
\hline L.S.D. at 5\% & 1.22 & 0.88 & 0.86 & 1.02 & \\
\hline \multicolumn{6}{|l|}{ Odor } \\
\hline 0 & $8.0 \pm 0.03$ & $9.0 \pm 0.00$ & $9.5 \pm 0.06$ & $9.5 \pm 0.09$ & 0.62 \\
\hline 5 & $7.3 \pm 0.01$ & $8.6 \pm 0.05$ & $9.5 \pm 0.02$ & $9.0 \pm 0.05$ & 0.84 \\
\hline 10 & $7.0 \pm 0.08$ & $8.3 \pm 0.08$ & $9.0 \pm 0.00$ & $8.6 \pm 0.02$ & 1.10 \\
\hline 15 & $5.5 \pm 0.11$ & $7.0 \pm 0.12$ & $8.5 \pm 0.11$ & $7.5 \pm 0.02$ & 0.70 \\
\hline 20 & $4.5 \pm 0.00$ & $6.5 \pm 0.01$ & $7.5 \pm 0.09$ & $7.0 \pm 0.05$ & 0.45 \\
\hline 25 & $3.5 \pm 0.09$ & $5.3 \pm 0.01$ & $6.5 \pm 0.00$ & $5.8 \pm 0.14$ & 0.48 \\
\hline L.S.D. at 5\% & 1.02 & 0.84 & 0.87 & 1.13 & \\
\hline \multicolumn{6}{|l|}{ Texture } \\
\hline 0 & $8.6 \pm 0.01$ & $8.6 \pm 0.05$ & $9.0 \pm 0.07$ & $9.0 \pm 0.00$ & 1.10 \\
\hline 5 & $8.5 \pm 0.11$ & $8.5 \pm 0.02$ & $9.0 \pm 0.05$ & $9.0 \pm 0.02$ & 0.55 \\
\hline 10 & $8.0 \pm 0.09$ & $8.5 \pm 0.02$ & $8.8 \pm 0.10$ & $8.5 \pm 0.02$ & 0.85 \\
\hline 15 & $6.5 \pm 0.00$ & $7.8 \pm 0.08$ & $8.0 \pm 0.06$ & $7.8 \pm 0.11$ & 0.45 \\
\hline 20 & $4.8 \pm 0.00$ & $7.0 \pm 0.00$ & $7.5 \pm 0.04$ & $7.5 \pm 0.09$ & 0.83 \\
\hline 25 & $3.5 \pm 0.12$ & $6.6 \pm 0.01$ & $7.0 \pm 0.11$ & $6.5 \pm 0.02$ & 1.02 \\
\hline L.S.D. at $5 \%$ & 0.72 & 0.22 & 0.46 & 0.54 & \\
\hline \multicolumn{6}{|l|}{ Overall acceptability } \\
\hline 0 & $8.2 \pm 0.01$ & $8.8 \pm 0.01$ & $9.3 \pm 0.01$ & $9.1 \pm 0.01$ & 0.50 \\
\hline 5 & $7.8 \pm 0.01$ & $8.6 \pm 0.01$ & $9.2 \pm 0.01$ & $9.0 \pm 0.01$ & 0.68 \\
\hline 10 & $7.4 \pm 0.01$ & $8.3 \pm 0.01$ & $8.8 \pm 0.01$ & $8.6 \pm 0.01$ & 0.55 \\
\hline 15 & $6.1 \pm 0.01$ & $7.3 \pm 0.01$ & $8.3 \pm 0.01$ & $7.7 \pm 0.01$ & 1.02 \\
\hline 20 & $4.5 \pm 0.01$ & $6.7 \pm 0.01$ & $7.5 \pm 0.01$ & $7.1 \pm 0.01$ & 0.48 \\
\hline 25 & $3.5 \pm 0.01$ & $5.8 \pm 0.01$ & $6.7 \pm 0.01$ & $6.2 \pm 0.01$ & 0.52 \\
\hline L.S.D. at $5 \%$ & 0.85 & 0.57 & 0.52 & 0.70 & \\
\hline
\end{tabular}

Mean values of 3 replicates \pm standard error. Mean values are significant and insignificant different ( $\mathrm{p}<0.05)$. Excellent (10-8.6), very good (8.5-7.6), good (7.5-6.6), accepted (6.5-5.0), poor (4.9-4) and very poor (3.9-0). 


\section{Conclusion:-}

In conclusion, the results obtained in this study showed the tested essential oils (EOs) of individualy1.0\% garlic, $1.0 \%$ ginger and $1.0 \%$ rosemary have antioxidative and antimicrobial properties that enhancement the physicochemical, microbiological and sensory quality attributes of raw Bayad fish sausage during cold storage thus, extending the shelf life. This is justified by the low TVB-N, TBA, and pH as well as bacteria, yeast and mold counts of fish sausage related with EOs than untreated control samples. Sensory evaluation revealed that shelf life of fish sausage samples was longest $(P<0.05)$ for samples treated with garlic, ginger and rosemary at $1.0 \%$ ( 25 days) as compared to the control (20 days) under storage at $4 \pm 1^{\circ} \mathrm{C}$. Therefore, the present findings recommended that the EOs of garlic, ginger and rosemary should be utilized for extending the shelf-life and enhancing quality attributes and sensory properties of fish sausage during cold storage as follows; sausage samples treated with $1.0 \%$ ginger, as the best treatment, followed by samples treated with $1.0 \%$ rosemary and finally treated with $1.0 \%$ garlic.

\section{References:-}

1. Abou-Taleb, M.; El-Sherif, S. and Elhariry, H. (2007): Preservation effect of four plant extracts used to extending the shelf-life of mullet fish fillets during cold storage. World J. of Dairy and Food Sci. 2 (2); 74-82.

2. Adam Sulieman, H. M.; Ali, M.T. and Tibin, M. I. (2011): Filleting yield and physical attributes of some fish from Lake Nubian. Online Journal of Animal and Feed Research, Volume 1; 412-416.

3. Ahmed-Egbal, O. and Elhaj-Ghada, A. (2011): The chemical composition microbiological detection and sensory evaluation of fresh fish sausage made from Clarias lazera and Tetradon fahaka. Journal of Fisheries and Aquaculture, Vol. 2; 11-16.

4. Akram, M.; Shah, M. I.; Usmanghan, K.; Mohiuddin, E. and Sami, A. (2011): Zingiber officinaleroscoe (A medicinal plant). Pakistan Journal of Nutrition, 10; 399-400.

5. Ali, F. H.; Kassem, G. M. and Atta-Alla, O. A. (2010): Propolis as a natural decontaminant and antioxidant in fresh oriental sausage. Veterinarian Italian, 46 (2); 167-172.

6. AOAC (2006): Official Methods of Analysis. Association of Official Analytical Chemists, Washington, D.C.

7. APHA (1992): American Public Health Association. In M. L. Speck (Ed.) compendium of methods for microbiological examination of foods. Washington, D.C.

8. Babatunde, O. A. and Adewumi, A. O. (2015): effects of ethanolic extract of garlic, roselle and ginger on quality attributes of chicken patties. African Journal of Biotechnology, Vol. 14 (8); 688-694.

9. Badee, A. Z. M.; El-Akel, A. T. and Thuraya A. A. (2013): Utilization of some essential oils to extend the shelflife of coated semi fried Nile perch fish fillets during cold storage. Journal of Applied Sciences Research, 9(6); 3508-3519.

10. Benjakul, S.; Visessanguan, W.; Phongkanpai, V. and Tanaka, M. (2005): Antioxidative activity of caramelisation products and their preventive effect on lipid oxidation in fish mince. Food Chemistry, 90; 231239.

11. Bonnel, A. D. (1994): Quality Assurance in Seafood Processing Ch. Quality Assessment, Academic Press, New York, USA, pp: 72.

12. Churi, S. S.; Yadav, B. M.; Chogale, N. D.; Gangan, S. S. and Basu, S. (2016): Recipe standardization and quality characterization of fresh and frozen fish sausage at different days of storage. Animal Science Reporter, Volume 10; 63-71.

13. Chytiri, S.; Chouliara, I.; Savvaidis, I. N. and Kontominas, M. G. (2004): Microbiological, chemical and sensory assessment of iced whole and filleted aquaculture rainbow trout. Food Microbiology, 21; 157-165.

14. Corbo, M. R.; Bevilacqua, A.; Campaniello, D.; Amato, D.; Speranza, B. and Sinigaglia, M. (2009): Prolonging microbial shelf-life of foods through the use of natural compounds and non-thermal approaches-a review. International Journal of Food Science and Technology, 44; 223-241.

15. EES (1991): (Egyptian Organization for Standardization and Quality Control) Egyptian standard specification for frozen sausage. ESS, Cairo.ES; 3-6.

16. El-Sherif, S. A. (2001): Chemical and technological studied on shrimp and its wastes. Ph. D. thesis, Fac. of Agric., Fayoum, Cairo Univ., Egypt.

17. Elagba Mohamed, H. A.; Al-Maqbaly, R. and Mohamed Mansour, H. (2010): Proximate composition, amino acid and mineral contents of five commercial Nile fishes in Sudan. African Journal of Food Science, Vol. 4(1 $0)$; 650-654.

18. EOS (2005): (Egyptian Organization for Standardization and Quality) Egyptian Standard, ES.

19. Erkan, N.; Tosun, S. Y.; Ulusoy,S. and Üretener, G. (2011): The use of thyme and laurel essential oil treatments to extend the shelf life of bluefish (Pomatomuss altatrix) during storage in ice. J. Verbr. Lebensm, 6; 39-48. 
20. Feldberg, R.; Chang S.; Kotik, A.; Nadler, M.; Neuwirth, Z.; Sundstorm, D. and Thompson, N. (1988): In vitro mechanism of inhibition of bacterial cell growth by allicin. Antimicrob Agents Ch. 32(12); 1763-1768.

21. Fisher, K. and Phillips, C. A. (2006): The effect of lemon, orange and bergamot essential oils and their components on the survival of Campylobacter jejuni, Escherichia coli $O_{157}: H_{7}$, Listeria monocytogenes, Bacillus cereus and Staphylococcus aureus in vitro and in food systems. J. Appl. Microbiol. 101 (6); 12321240.

22. Gafar, M. K.; Itodo, A. U.; Warra, A. A. and Abdullahi, L. (2012): Extraction and physicochemical determination of garlic (Allium sativum) oil. International Journal of Food and Nutrition Science, 1(2).

23. Gomez, K. A. and Gomez, A. A. (1984): Statistical procedures for agriculture research. John Wiliy and Sons Editor Inc. USA (2Ed.), Chapter 3; 129-184.

24. Gomma, R. A. M. (2005): Studies on producing sausage from some fish types. M. Sc. thesis, Fac., of Agric., Al-Azhar Univ., Egypt.

25. Gonza'lez-Fandos, E.; Sierra, M. L.; Garcia-Lopez, M. L.; Otero, A. and Sanz, J. (1996): Effect of the major herbs and spices in Spanish fermented sausage on Staphylococcus aureus and lactic acid bacteria. Arch. Lebensmittelhyg, 47; 43-47.

26. Huda, N.; Alistair, T. L. J.; Lim, H. W. and Nopianti, R. (2012): Some quality characteristics of Malaysian commercial fish sausage. Pakistan Journal of Nutrition 11 (8); 700-705.

27. ICMSF (2002): International Commission on Microbiological Specification for Food: Microorganisms in Foods 2. Sampling for microbiological analysis: Principles and specific applications $\left(2^{\text {nd }}\right.$ Ed.).University of Toronto Press, Toronto. Canada.

28. Iheagwara, M. C. (2013): Effect of ginger on stability and sensory quality of smoked mackerel (Scomber scombrus) fish. J Nutrition Food Sci. 3; 199-203.

29. Kassem, G. M.; Atta-Alla, O. A. and Ali, F. H. M. (2011): Improving the quality of beef burger by adding thyme essential oil and jojoba oil. Arch. Zootec., 60 (231); 787-795.

30. Khallaf, M. F. (1990): Properties of smoked sausage processed from common carp fish. J. Agric. Sci. Mansoura Univ. 15 (18); 1288-1299.

31. Kykkidou, S.; Giatrakou,V.; Papavergou, A.; Kontominas, M. G. and Savvaidis, I. N. (2009): Effect of thyme essential oil and packaging treatments on fresh Mediterranean swordfish fillets during storage at $4{ }^{\circ} \mathrm{C}$. Food Chemistry, 115; 169-175.

32. Mexis, S. F.; Chouliara, E. and Kontominas, M. G. (2009): Combined effect of an oxygen absorber and oregano essential oil on shelf life extension of rainbow trout fillets stored at $4^{\circ} \mathrm{C}$. Food Microbiology, 26; 598-605.

33. Nakatani, N. (1994). Antioxidative and antimicrobial constituents of herbs and spices, in: Spices, Herbs and Edible Fungi (ed. G. Charalambous). Elsevier Science, New York, pp. 251- 271.

34. Oliveira, A. C. M. (2014): Development and characterization of fish sausage supplemented with salmon oil. Journal of Food Processing and Preservation, 38 (4); 1641-1652.

35. Osheba, A. S.; Shams El-Din, N. M. M. and Hussien, S. A. (2010): Effect of some herbs on the quality of irradiated beef sausage preserved by cold storage. ISOTOPE \& RAD. RES., 42(4); 925-947.

36. Ozogul, Y.; Ozogul, F.; Kuley,E.; Ozkutuk, S.; Gokbulut, C. and Kose, S. (2006): Biochemical, sensory and microbiological attributes of wild turbot (Scophthalmus maximus), from the Black Sea, during chilled storage. Food Chemistry, 99; 752-758.

37. Özpolat, E.; Patır, B.; Guran, H. S. and Gul, M. R. (2014): Effect of vacuum-packing method on the shelf-life of Capoetaumbla sausage. Iranian Journal of Fisheries Sciences, 13(1);178-184.

38. Pearson, D. (1991): The Chemical Analysis of Food. Churchill, New York, London, PP: 374-410.

39. Riznar, K.; Celan, S.; Knez, Z.; Skerget, M.; Bauman, D. and Glaser, R. (2006): Antioxidant and antimicrobial activity of rosemary extract in chicken frankfurters. Food Chemistry and Toxicology, 71; 425-429.

40. Sacchetti, G.; Maietti, S.; Muzzoli, M.; Scaglianti, M.; Manfredini, S.; Radice, M. and Brni, R. (2005): Comparative evaluation of 11 essential oils of different origin as functional antioxidants, antiradicals and antimicrobials in foods. Food Chem., 91; 621-632.

41. Salem-Amany, M.; Amin-Reham, A. and Afifi-Gehan, S. A. (2010): Studies on antimicrobial and antioxidant efficiency of some essential oils in minced beef. Journal of American Science, 6(12); 691-700.

42. Sallam, K. I.; Ishioroshi, M. and Samejima, K. (2004): Antioxidant and antimicrobial effect of garlic on chicken sausage. Lebenson Wiss Technol., 37(8); 849-855.

43. Salvat, A; Antonnacci, L; Fortunato, R. H.; Suarez, E. Y. and Godoy, H. M. (2001): Screening of some plants from Northern Argentina for their antimicrobial activity. Lett Appl Microbiol, 20; 32 (5); 293-297.

44. Shelef, L.; Naglik, O. and Bogen, D. (1980): "Sensitivity of some common food-borne bacteria to the spices sage, rosemary and allspice”, J. Food Sci., 45; 1042- 1044. 
45. Sikkema, J.; DeBont, J. A. M. and Poolman, B. (1994): Interactions of cyclic hydrocrbons with biological membranes. J. Biol. Chem., 269(11); 8022-8028.

46. Singh, G.; Marimuthu, P.; Murali, H. and Bawa, A. (2005): Antioxidative and antibacterial potentials of essential oils and extracts isolated from various spices materials. J Food Safety, 25; 130-145.

47. Siu, G. M. and Draper, H. H. (1978): A survey of the Malonaldehyde content of retail meats and fish. J. Food Sci., 43; 1147-1149.

48. Stansby, M. E. (1982): Properties of fish oils and their application to handling of fish and to nutritional and industrial use. In: Chemistry and Biochemistry of Marine Food Products. (Martin, R. E.; Flick G. J.; Hebard, C. E. and Ward, D. R. Eds.). pp. 75-92. Avi Publishing Co., Westport, CT.

49. Suman, S. P.; Mancin, R. A.; Joseph, P.; Ramanathan, R.; Konda, M. K. R.; Dady, G. and Yin, S. (2010): Packaging-specific influence of chitosan on color stability and lipid oxidation in refrigerated ground beef. Meat Sci., 86; 994 - 998.

50. Ucak, I.; Ozogul, Y. and Durmus, M. (2011): The effects of rosemary extract combination with vacuum packing on the quality changes of Atlantic mackerel fish burgers. International Journal of Food Science and Technology, 46; 1157-1163.

51. Yassin-Nessrien, M. N. and Abou-Taleb, M. (2007): Antioxidant and antimicrobial effects of Marjoram and thyme in coated refrigerated semi fried mullet fish fillets. World J. Dairy \& Food Sci. 2 (1); 1-9.

52. Zakipour, R. E. and Divband, M. (2012): The effects of coating and Zatariamulti floraboiss essential oil on chemical attributes of silver carp fillet stored at $4^{\circ} \mathrm{C}$. International Food Research Journal, 19(2); 685-690.

53. Zia-ur-Rehman; Salariya, A. M. and Habib, F. (2003): Antioxidant activity of ginger extract in sunflower oil, J. Sci. Food Agric., 83; 624-629. 